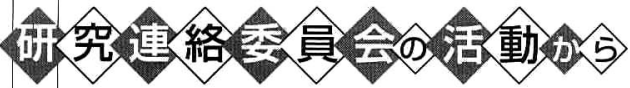

の要請となっている。

歴史を振り返れば、第2次大戦前、我が国は情報の収 集、分析、管理、活用の拙劣さから致命傷を蒙り、その 教訓を生かすことなく、1990年代の日米経済戦争に敗れ 去った。

しかし、今、企業などでは、情報の管理、活用が盛衰 の決めてとなることに気づき始めた。IT化の波は今度こ そ、我々の内部の精神を動かすに違いない。

\section{学際的情報セキュリティ総合科学の 体系化に向けて}

上にその一端に触れた情報セキュリティは、自由・平 等・安心を理念とするIT社会構築の基盤であり、暗号、 セキュアOSなどの技術、デジタル・フォレンジックな どのセキュリティ管理・運営、経営・経済、組織論、個
人情報保護法や電子署名法などの法律、情報倫理などの 視点からの総合的対策により、ITによってもたらされる 利便性や効率性との矛盾を解決して調和統合を図るもの である。從って、学術的には、学際的な総合科学という ことになる。そのような学問のダイナミックな体系化に 向けて、2004年11月、21日から3日間、基盤情報通信研 究連絡委員会、日本セキュリティマネジメント学会、中 央大学COE、情報セキュリティ大学院大学の主催の下 に、文理にまたがる20余りの学会等に呼びかけて、学際 的情報セキュリティ総合科学シンポジウムを開催し、活 発な議論を展開した。

情報セキュリティは、学術会議におりて未だ市民権を 得ていないと実感しているが、それは、第1部から第7部 までの全学問領域に広がる分野であることをご認識頂 き、今後ともご支援賜れば幸いである。

辻井重男（つじい しげお 1933年生）

日本学術会議第5部会員、情報セキュリティ大学院大学学長 専門：暗号理論、情報セキュリティ総合科学

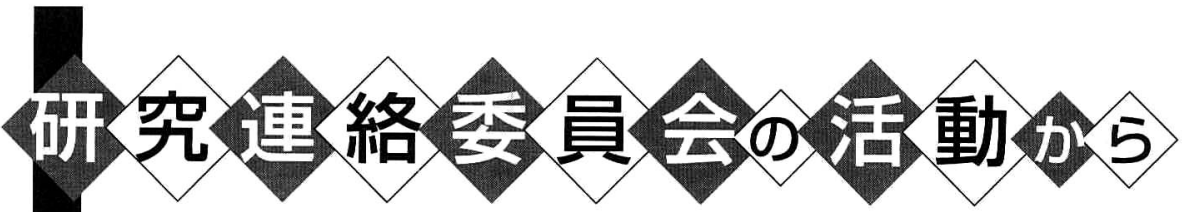

\section{測地学分野と情報通信分野との 研究連携}

\section{— 第3回e-VLBI国際ワークショップ開催報告}

固体地球物理学研究連絡委員会測地学専門委員会では、 2004年10月6日から7日にかけて、幕張プリンスホテル（千 葉県千葉市）を会場として第3回国際e-VLBIワークショッ プを主催した。このワークショップは、2002年に米国マサ チューセッツ工科大学ヘイスタック観測所で開催されてか ら年に1回開催されており、今回初めて日本で開催するこ とになったもので、13力国から67名の参加者を得て活発な 研究発表と意見交換が行われた。
このワークショップの目指すものは、測地学や電波天文 学の研究者と情報通信分野の研究者とが一同に会し、掗 いの情報交換を通じて協力して分野融合型の研究開発を進 めるところにある。本報告では、このワークショップの開 催に至った背景を述べることを通じて、測地学研究を核と して他分野研究との融合による発展を探る典型例として、 その展望について記したい。 


\section{e-VLBI}

超長基線電波干渉法（Very Long Baseline Interferometry：VLBI）は、複数の電波望遠鏡で受信し た天体電波の信号を干渉処理することで、高解像度の天 体電波源イメージを合成する観測技術である。単体の電 波望遠鏡はごく粗い解像度でしか天体電波源の輝度分布 を調べることができないが、VLBIでは、電波望遠鏡間の 距離の開口径をもつ電波望遠鏡に相当する角度分解能を 得ることができる。その結果、ハッブル宇宙望遠鏡や地 上の大型光学望遠鏡をはるかに凌ぐ解像度で天体のイメ ージを得ることが可能となるため、天文学にとって非常 に重要な観測手段となっている。

また、受信信号間の遅延時間を精密に計測できること を利用して、VLBIは測地学研究にも大きな変革をもたら した。1980年代にプレート運動が初めて直接の測定によ って実証されたことをはじめ、現在では地球基準座標系 および天球基準座標系の定義にVLBIの観測成果がその基 礎として使われている。ところが、従来行われてきた国 際VLBI観測では、観測したデータを磁気テープに記録し、 その磁気テープを相関处理と呼ばれるデータ処理を行う ために相関処理局に輸送する必要があったことなどから、 解析結果を得るまでに数日から数週間を要していた。そ こで、高速なネットワーク接続を利用して、観測データ を電子的に相関処理局に伝送することで、従来のVLBI観 測よりも短時間で解析結果を得ようとするのが $\mathrm{e}-\mathrm{VLBI}$ ある。

e-VLBIによってリアルタイムにVLBII観測データを処理 することができるようになれば、VLBI観測データを時間 遅れなく解析することができるようになるほか、処理の 自動化が進んで地球姿勢の計測を連続して行うことなど が現実的になるなど、測地学研究におけるブレークスル 一が期待される。また、電波天文では、観測データレー トを増やすことが感度の向上につながることから、磁気 データレコーダーの能力によるデータレートの限界を払 拭し、感度を大幅に向上することができると期待される。 感度が飛躍的に向上すれば、これまではVLBIによる観測 が困難であった恒星の熱的電波など、微弱な天体電波源 を観測対象にすることができるようになり、電波天文学
にとっても大きな意味を持つ。

\section{情報通信分野と融合した測地学研究}

測地学に抢ける研究の進展は、計測技術の発達と表䯧 一体の関係にあり、これまで新しい計測技術の登場が幾 度となく測地学研究にブレークスルーを起こし発展を続 けている。VLBI、SLR、GPSに代表される宇宙測地技術 の研究開発がもたらした变革は、現在の測地学研究の基 盤となっていると言ってよい。一方、昨今の情報通信技 術の急速な進展は、従来は考えられなかったような膨大 なデータを瞬時に遠距離の地点間でやりとりすることを 可能としつつある。そして、このことは、社会生活や経 済活動に大きな変革をもたらしつつあるとともに、測地 学研究においてさらなる飛躍をもたらそうとしている。

e-VLBIは、本質的に極めて膨大なデータを地理的に離 れた地点間で伝送し、合成処理を行うことが必要な研究 課題であり、高速なネットワーク技術を科学計測の分野 へと応用する典型的な例である。また、e-VLBIで要求さ れる多地点間での膨大なデータ伝送や、マルチキャスト と分散処理によるネットワーク資源や計算資源の効率的 利用などをインターネット環境で実現することは、ネッ トワーク技術の研究開発にとっても好適な技術開発課題 であり、これらの課題を解決することは、さらなるネッ トワーク技術の進展に寄与するものと期待される。

その意味で、異なる研究分野の研究者が最新の成果を 報告しあい、今後の進め方を議論する今回のワークショ ップのような機会には大きな意義がある。研究分野間の 融合や交流の重要性が叫ばれる中、このような研究集会 を積極的に活用していくことはますます重要になってい くであろう。

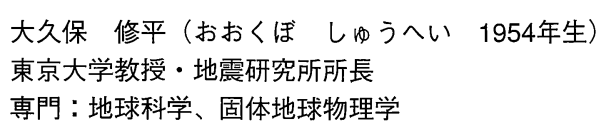

